\title{
ON THE SPATIO-TEMPORAL APPROACHES TOWARDS CONSERVATION OF EXTENSIVELY MANAGED RURAL LANDSCAPES IN CENTRAL-EASTERN EUROPE (short running title: spatio-temporal approaches in extensive $\mathrm{CE}$ European rural landscapes)
}

\begin{abstract}
KINGA ÖLLERER
Institute of Biology - Romanian Academy. Ecology, Taxonomy and Nature Conservation Department, Spl. Independenei 296, 060031 Bucharest, Romania, phone: +40-21-2219202, fax: +40-21-221-9071, e-mail: kinga.ollerer@gmail.com
\end{abstract}

Received: $6^{\text {th }}$ March 2013, Accepted: $10^{\text {th }}$ June 2013

\begin{abstract}
Land-use change is one of the major drivers of global biodiversity loss, its study experiencing continuous development and increasing recognition, influencing main research directions within ecology. Many studies target the negative aspect; however, the modification of the natural environment over centuries and millennia led to the biodiversity, in its broadest sense, we are trying to conserve nowadays within cultural landscapes. This theoretical paper deals with the issue of spatial and temporal variations in extensively managed rural landscapes from Central-Eastern Europe. The constraints of the state of the art and arising challenges for biodiversity management in complex, farmed landscapes of high nature conservation value are discussed, through the example of Transylvania (Romania). The paper argues for the necessity of considering historical perspectives and traditional knowledge in an attempt to understand the current on-site conditions and developing realistic adaptive management strategies with special emphasis on the (traditional) rural communities, representing a key resource for biodiversity conservation.
\end{abstract}

Keywords: traditional practices, farmed landscapes, semi-natural areas, biodiversity conservation

\section{INTRODUCTION}

Converting natural landscapes for human use or changing management practices on already human-dominated lands have transformed a large proportion of the Earth's land surface. This has resulted in major modifications of biodiversity and modifications of the global carbon cycle and hydrologic cycle (Foley et al., 2005; Fahrig, 2007), since the effects of land transformations extend far beyond the boundaries of the transformed lands (Vitousek et al., 1997).

European farmed landscapes, developed following a long tradition of land-use, are currently being threatened by the changes occurring in the interaction between humans and the natural environment. This interaction has, since the end of the glaciation and until 
recently, facilitated the long-term development of a specific biodiversity (Green et al., 2005; Plieninger et al., 2006; Pedroli et al., 2007). On the other hand, land-use changes are considered one of the most complex (Huston, 2005) and major drivers of biodiversity loss, negatively affecting both pristine areas and farmed landscapes (Foley et al., 2005, and most of the literature cited throughout this paper).

Although the importance of land-use is now well accepted, and currently influencing some of the main research directions within ecology, this is a relatively new situation. Throughout much of its history, in ecology it was worked with spatial homogeneity, without considering the heterogeneity of space and the temporal dynamics of landscapes (Pickett and Cadenasso, 1995). Among the first researchers who recognised that spatial heterogeneity is a central causal factor in ecological systems (Pickett and Cadenasso, 1995; Wagner and Fortin, 2005) was Carl Troll, who coined the term landscape ecology in 1939 and developed many of its early concepts (Troll, 1939). The importance of temporal aspects was subsequently included, through the development of the island biogeography theory (immigration, emigration and extinction, MacArthur and Wilson, 1967) and of the metapopulation model (time delays in metapopulation response, Levins, 1969), and the more recent spatially realistic metapopulation theory, which represents a synthesis of the previous two (Hanski, 2001).

Following these theoretical developments, doubled by the advance in technological capacity, landscape perspective and land-use began to occupy a central position in environmental management (see for example the efforts of the European Commission in ensuring that environmental concerns are taken into account when building up land-use development plans - http://ec.europa.eu/environment/archives/land_use/index_en.htm) and ecological economics, permitting the consideration of various aspects and interests and their graphic interpretation through maps and modelling. At present, landscape planning and landscape ecology are strongly interacting both at theoretical and practical levels, encompassing various knowledge from fundamental research to different applications.

As research data started to accumulate, and more and more questions were raised about what were the driving forces that formed the present landscapes and determined the complex interactions between species, the importance of land-use history to theoretical ecology and conservation practice became increasingly recognised (Ericsson et al., 2002; Dutoit et al., 2003; Foster et al., 2003; Cousins, 2009; Rick and Lockwood, 2012). In the era of (technological) specialisation, this finding turned researchers back to old documents, historical maps and traditional knowledge in their attempt to unravel as much as possible about the interaction between land-use history and ecosystem processes. This situation is characteristic especially for Europe, where farmland biodiversity, developed following the long-term interaction between humans and the natural environment, is considered just as valuable as wild biodiversity (Plieninger et al., 2006; Pedroli et al., 2007).

The aim of this paper is not to review the existing body of literature on farmland biodiversity, but rather to bring into discussion some of the challenges that these areas represent for conservation scientists and practitioners, citing studies all over Europe, but with a special emphasis on Central and Eastern Europe, and particularly on Transylvania (Romania). These challenges are resulting from the determinant characteristics of the Central and Eastern European landscapes: namely, no sharp delimitation between "wild nature" and inhabited areas in the countryside, due to the high percentage of rural communities still practicing extensive (traditional) farming, as well as low or complete lack of fragmentation resulting from infrastructural development. These factors have culminated in a wide occurrence of species and habitats already lost or highly protected in Western Europe (Akeroyd and Page, 2006; Schmitt and Rákosy, 2007; Mikulcak et al., 2013). 


\section{The importance of the landscape approach}

After a long history of nature conservation efforts limited only to "wild nature", recently there has been an increasing recognition that this has only a limited effect, discounting an important part of biodiversity (e.g. urban- and agro-biodiversity). While urban biodiversity, in many cases, only represents a remnant of the past, agricultural management has often been shown to enhance biodiversity and ecosystem functions, especially in the traditional cultural landscapes (Phillips, 1998), which are becoming fragmented with an increasing pace and scale, facing major compositional and functional modifications (Antrop, 1997; Eetvelde and Antrop, 2009). As a result, land-use is becoming variegated in many areas around the world, and understanding the effects of this process, from the perspective of biodiversity conservation and ecosystem services, requires a large scale perspective or a landscape-level approach (Tscharntke et al., 2005).

If the aim is to understand ecosystem processes, it is important not to adopt an isolated approach to ecological systems, which are open and interacting by nature and have a historical character (Baudry, 1989). A binary delimitation - into agricultural and natural (ecological) systems - is in many cases impossible; for example, in the wide extensive landscapes of Transylvania, Romania, where traditional small-scale farming practices have developed, and continue to maintain, extensive areas of high nature value (Akeroyd and Page, 2006; Beaufoy et al., 2008; Mikulcak et al., 2013) due to the complexity of the landscape composition, as well as the interconnectedness of ecological systems forming the landscapes (Jongman, 2002). Besides, a binary approach might have negative outcomes. Excluding the existence of interactions would only accelerate the ongoing polarisation and homogenisation (loss of regional differences) between urban areas and rural/natural landscapes, followed by segregation of land-uses, increasing abandonment of countryside and inherent biodiversity losses (Jongman, 2002; Antrop, 2004; McIntyre, 2007). In the era when humans achieved the ability to influence directly or indirectly all ecosystems (Foley et al., 2005), a complex approach, based on the study and assessment of interactions and its reflection in conservation management and planning activities, is compulsory (Antrop, 1997; Theobald et al., 2000; Jongman, 2002).

The importance of considering interactions and the complexity of relationships which influence biodiversity, and therefore the necessity of such an approach in management practices, was shown by several authors (e.g. Houlahan et al., 2006, Van Noordwijk et al. 2004 etc.). These studies highlighted the necessity that landscape connectivity, and the dispersal and movement of organisms, has to be considered in relation to species richness dynamics, and that biodiversity research methods can and should extend in order to clarify causal relations (Van Noordwijk et al., 2004). They also concluded that in many cases, especially in cultural/traditional landscapes which will be discussed further, the ecological knowledge of locals has to be explored as an integral part of a landscape ecological approach. This will lead to a better understanding of these ecosystem complexes, and help to achieve "integrated natural resource management".

A large body of literature includes the conclusion that, as a growing fraction of the Earth's surface is heavily influenced by human activities, the future of biodiversity depends to a great extent on the biodiversity conservation in the countryside, based on an approach that considers the diversity of landscapes and multiple habitats (Pereira and Daily, 2006).

The importance of multi-habitat and landscape approach is perhaps even better explained through the example of mobile organisms and landscape species (Kremen et al., 2007; Sanderson et al., 2002). For example, many ecosystem services (e.g. pollination) are delivered by organisms depending on habitats that are spatially or temporally disconnected, occurring more likely in regions with habitat heterogeneity, in what is often called a 
habitat/landscape matrix (Kremen et al., 2007). Habitat heterogeneity is therefore important for the stability of populations, larger landscape scales having the strongest effects on the population dynamics of multi-habitat/“wider-countryside" species (Oliver et al., 2010).

\section{The challenge of land-use studies in complex, farmed landscapes}

"Biodiversity conservation will not work

without protecting the just $5 \%$ remaining

pristine habitats, but also not without

a recognition of the contribution of the 'rest'."

(Tscharntke et al., 2005).

Farming is one of the major drivers of global land-use change, but its effects vary depending on the intensity and location of use, and whether we are talking about monoculture cropland systems or about multi-use rural areas. In tropical countries, farming continues to result in major biodiversity losses, while in Europe there are several species that tolerate and even require moderate-yield farming, and the negative effects appear only when the intensity and applied practice is modified or abandoned (Balmford et al., 2005; Kleijn et al., 2009).

While for several decades the general tendency was to study biodiversity mainly in unmanaged (natural, pristine) areas, the recognition that land-use changes are occurring all around the globe, modifying the global carbon cycle, as well as the regional and, possibly, global climate, causing severe changes in biodiversity (Foley et al., 2005) turned scientists more towards semi-natural, cultural landscapes (Phillips, 1998; Vitousek et al., 1997; Mattison and Norris, 2005; McIntyre and Lavorel, 2007; Pedroli et al., 2007; Plieninger and Bieling, 2012).

This is mainly the case in Europe, the most densely populated continent, where the long and complex habitation history is reflected in a great variety of landscapes, encompassing several land-use categories and characteristic biodiversity, strongly dependent on a medium degree of human impact (Plieninger et al., 2006; Pedroli et al., 2007; Halada et al., 2011). In the western part of the continent, natural areas are present only as remnants, and conservation efforts are increasingly oriented towards semi-natural habitats, and the continuation, reintroduction or mimicking of traditional practices (Wright et al., 2012). Meanwhile, Central and Eastern European landscapes claim for increasing attention. Although traditional practices and the entire rural livelihood are still characteristic in these areas, landscape changes are ongoing, and the stability of these areas is only apparent (Urbanc et al., 2004; Palang et al., 2006). Such landscapes represent a challenge for ecological research and management due to their complex use, the variety of related interests, and the difficulty of providing ecological data and analysis in a format and language that is understood by all who are developing plans, and who are to be affected by the resulting decisions (Bouma et al., 1998; Theobald et al., 2000; Van Noordwijk et al., 2004; Mattison and Norris, 2005; Plieninger et al. 2006; Pocewicz et al., 2008; Mikulcak et al., 2013).

A special situation is that of agricultural landscapes, since most areas with agricultural land-use are spatially overlapping with areas of high biodiversity importance (Mattison and Norris, 2005; McIntyre and Lavorel, 2007). In areas where extensive large-scale agriculture developed a characteristic biodiversity, the modification of traditional practices is leading to biodiversity loss, just as in the case of natural landscapes affected by land-use change. This is leading to the modification and fragmentation of habitats, degradation of soil and water and over-exploitation (Foley et al., 2005; Mattison and Norris, 2005; McIntyre and Lavorel, 2007). 


\section{The conservation value of rural landscapes}

"The increasing pace and scale of landscape change

initiated a renewed interest in cultural

and heritage values of the landscape."

(Eetvelde and Antrop, 2009).

Worldwide, land-use changes are influencing various ecosystems, shaping and determining the dynamics of natural, modified or completely artificial areas, often conducting to irreversible modifications (see Vitousek et al., 1997 and Foley et al., 2005 for a review). However, research efforts were not reflecting this fact for a long time, and were mainly concentrated on natural areas, avoiding the study of rural, agricultural systems (McIntyre and Lavorel, 2007).

Until recently, most of the land-use studies focused on the causes and consequences of land-use change in natural areas (e.g. detrimental modifications like deforestation, expansion of urban areas and croplands). This was also reflected in biodiversity conservation efforts. Only a few decades ago the most frequent conservation practice was that of nature reserves, located whenever possible in strictly delimited areas, and concentrated mainly on species. Nowadays, as a result of increasing knowledge regarding biological diversity, conservation efforts are more oriented towards habitats, including areas also inhabited by humans. This shift in approach was to be expected, considering the accumulation of data showing major and unique conservation values, resulting mainly from the great landscape and habitat heterogeneity in previously neglected areas, like the traditional farmlands. Conservation focus on these areas is of great actuality, since in many cases there is an overlap between agricultural land-use and biodiversity-rich areas, where the continuation of appropriate management is the key for maintaining biodiversity. As a result, rural, traditional, cultural landscapes and their characteristic land-use and biodiversity occupy a special place in the last few years of ecological research (for a selection of studies, see the reference list) and conservation practice. Such conservation efforts are found, for example, in the conception behind the Natura 2000 network of protected areas in Europe (e.g. the importance of maintaining traditional practices for biodiversity), the concept of Biosphere Reserves, the Pan-European Biological and Landscape Diversity Strategy, adopted in 1995, the appearance of Landscape Reserves, the adoption of the European Landscape Convention in 2000, the continuously increasing list of cultural landscapes recognized by UNESCO etc.

The High Nature Value (farm-/ grassland (HNV) concept (Baldock et al., 1993) appeared also as a recognition that a significant part of the biodiversity of Europe lies on farmlands, being strictly dependent on extensive management practices (discussed e.g. by Paracchini et al., 2008, European Forum on Nature Conservation and Pastoralism - www.efncp.org). The identification and protection of HNV lands is encouraged by the European Union through the Rural Development Programmes.

It hat been shown that several species and habitats of conservation interest depend on low-intensity agricultural management (Halada et al., 2011; Wright et al., 2012). As a result, the smaller scale and less obvious land-use changes, like the modification of traditional practices (e.g. abandonment, mechanisation, and change in frequency) are receiving increasingly growing attention, bringing out valuable findings that are highlighting the major potential losses (biodiversity in its largest sense, encompassing species, cultural and knowledge diversity) related to these changes (Rabbinge and van Diepen, 2000; Urbanc et al., 2004). Rural landscapes, through their inhabitants, are bearers of invaluable traditional knowledge regarding land-use history, dynamics and specific practices needed for their maintenance; knowledge that has been shown to be comparable to 
scientific findings (Molnár and Babai, 2009; Babai and Molnár, 2013), and that is still active in more remote and less developed areas, especially in Central and Eastern Europe.

Agriculture is one of the main drivers of biodiversity decline, but extensive, traditional agricultural land-use applied in several farmlands still supports high levels of biodiversity, calling also for immediate intervention towards their conservation (Bignal and McCracken, 1996; European Environmental Agency, 2004; Hietala-Koivu et al., 2004; Pedroli et al., 2007; Kleijn et al., 2009). More than 50\% of Europe's most highly valued biotopes occur in low-intensity farmlands (Bignal and McCracken, 1996). Out of the 231 habitats listed in Annex I of the Habitats Directive (Council Directive 92/43/EEC on the conservation of natural habitats and of wild fauna and flora, EC 1992), which includes habitats of conservation interest requiring protection, 63 have been shown to be fully (23) or partly (40) dependent on agricultural practices (Halada et al., 2011). Therefore, the knowledge regarding still ongoing or already forgotten traditional practices is gaining importance in the view of scientists and policy makers.

Traditional, rural, cultural landscapes evolved during centuries, and are bearers of a strong identity and specific biodiversity, resulting mainly from the great landscape and habitat heterogeneity that characterises these areas and puts them against modern, uniform landscapes (Antrop, 1997; Plieninger and Bieling, 2012). Before the recognition of their unique value, and even afterwards (Strijker, 2005), these landscapes were and continue to be condemned for disappearance in most of Western Europe and many other areas of the world, becoming only fragments of their previous extent, isolated patches in a uniformed space (Antrop, 1997).

Traditional landscapes act as proof of the strong connection between environment, economy and social issues (Urbanc et al., 2004), being also a very didactical example of how changes in one of these components is reflected by all three, which highlights the challenge and importance of their study. Although they are mostly linked to the history of mankind, land-use states and transitions are still poorly understood in traditional landscapes due to their complexity, which explains in a way the large number of decisions that continue to affect traditional landscapes in a period when there are increasingly more efforts working towards their conservation (McIntyre and Lavorel, 2007). Because both natural prerequisites and history (social, cultural and economical - reflected in land-use) are reflected in their present-day state (Urbanc et al., 2004), traditional landscapes are increasingly recognised as important reference areas that might provide good examples for sustainability.

Spatio-temporal variations have a great importance in the study of traditional landscapes, since these areas evolved after a long history of various land-uses. These variations are visibly reflected by the vegetation cover, while changes are occurring in all communities, all with different spatial requirements and different responses to temporal variations and changes. Therefore, the outcome of biodiversity studies of the different land-uses largely depends on several factors operating at stand- and landscape-scale, and on the selection of variables measuring these factors (Felton et al., 2010).

\section{Traditional land-use practices and biodiversity - the example of Transylvania (Romania)}

The long history of land-use in Europe has led to the development of specific landscapes, and new habitats have appeared that depend on human maintenance. These new habitats created by a continuous and stable management are in a dynamic equilibrium on which depends the survival of several rare and threatened species, requiring the complex mosaic of patches that characterises traditional landscapes in Transylvania, Romania (Cowell, 
2007). The level of farmland biodiversity is exceptionally high in this part of Europe, due to the traditional practices that still exist (Akeroyd and Page, 2006; Schmitt and Rákosy, 2007; Beaufoy et al., 2008; Mikulcak et al., 2013). A recent study showed that the composition of a representative traditional rural landscape is still suitable for several amphibian species, a group highly sensitive to landscape composition; the authors concluding that the lack of correlation between landscape compositional measures and the distribution of amphibians is explained by the traditional management of these landscapes, that provides favourable environmental conditions for these demanding species (Hartel et al. 2010). These landscapes still retain high biodiversity in good conservation status, however, the fact that the high nature value character is valid for such a vast area makes it clear that the way forward is the integration of biodiversity conservation, rural development and agricultural policy, as a proactive approach (Schmitt and Rákosy, 2007; Cogălniceanu and Cogălniceanu, 2010; Mikulcak et al., 2013).

A major threat affecting the characteristic biodiversity of these landscapes is the disrupting habitat continuity, a result of the modification of the traditional practices that led to their appearance and development. For example, the main threats to the biodiversity of the Transylvanian farmlands are the intensification (mechanisation of use, fertilisation, increased grazing periods and grazing stock rates), abandonment and infrastructural development, related both to the collapse of socialism and to the recent demand for increased production following Romania's access to the European Union (Schmitt and Rákosy, 2007; Beaufoy et al., 2008; Mikulcak et al., 2013). However, these small-scale changes are not shown in documents and maps, the areas being henceforward classified as pastures or meadows even a long time after the effects started to be reflected by species composition, abundance and distribution pattern (Ruprecht et al., 2010); this is also having a strong impact on the prediction of landscape dynamics (Fang et al., 2006). Therefore, gathering data about (traditional) management practices requires a very important documentation phase. The most commonly used data sources are: historical, topographical maps, orthophoto maps, toponyms, old registers and descriptions (Sousa and GarcíaMurillo, 2001; Dutoit et al., 2003; Eetvelde and Antrop, 2009), the outcomes of more recent technological advances like Geographical Information System applications (Plieninger et al., 2006; Eetvelde and Antrop, 2009), previous biodiversity surveys (Enyedi et al., 2008, Ruprecht et al., 2010), interviews with locals (Cowell, 2007) etc.

The study of traditional land-use practices has to consider the history and frequency of the practice in cause (grazing, cutting of trees and shrubs, mowing etc.). For example, temporary abandonment, a basic characteristic of traditional rotational grassland management, has been acknowledged to favour a great variety of species, highlighting the high conservation value of maintaining simultaneously different succession stages (Baur et al., 2006). Still, caution is needed when discussing this issue, since this temporary abandonment should not be mistaken for long-term abandonment, usually associated with negative effects on biodiversity. Grassland abandonment allows natural succession, favouring litter accumulation, shrub encroachment, the penetration of more shade-tolerant species and finally afforestation. This leads to major changes in species composition, to the disappearance of several species of conservation interest, that depend on the existence of open areas and even to the disappearance of entire characteristic landscapes (Schneider and Gry, 2005; Plieninger et al., 2006; Cowell, 2007; Ruprecht et al., 2010).

The complete abandonment of previous uses implies the loss of a traditional landscape, leading to the loss of many ecosystem functions, habitat and species diversity, and also historical and cultural identity (Noir-Meir et al., 1989). In contrast, the intensification of land-use reduces functional redundancy (meaning the number of species contributing 
similarly to an ecosystem function) and response diversity (how functionally similar species respond differently to disturbance) of communities, ultimately affecting the adaptation capacity of ecosystems and resilience (Laliberté et al., 2010).

\section{CONCLUDING REMARKS}

In the era of global land-use change, the importance of both recent events and historical processes became increasingly recognised, calling for the need of taking into account landuse history besides the present-day situation, both in theoretical ecology and conservation practice (Rick and Lockwood, 2012). This also meant a major shift in the methodologies applied during these studies, which are nowadays encompassing a large variety of techniques (e.g. modelling applications, GIS, complex statistics). All of these factors, combined with theoretical development, allow increasingly complex spatial and temporal analyses, including estimations of the effects of land-use change - scenario analyses.

The above cited papers give a short glimpse on the conservation importance of traditional land-use practices, and also on the challenge of demonstrating how even small changes can lead to significant biodiversity loss, calling for the need of an integrated approach whenever land-use modification is discussed.

The outcome of conservation efforts is strongly influenced by how we describe the systems we want to conserve, how intervention targets are defined and what measures are applied for meeting these targets. Although there are several policy measures that directly or indirectly aim to contribute to the conservation of farmland biodiversity in Europe (the Natura 2000 network, the agri-environmental schemes of the Common Agricultural Policy, the Rural Development Programme etc.) these are often poorly adapted to the local conditions and therefore cannot fulfil the task. This is especially true in complex landscapes, and their effectiveness is questionable in comparison with the associated costs (Kleijn and Sutherland, 2003, Kleijn et al. 2007; Scheper et al., 2013). For example, the Natura 2000 network is the main European biodiversity conservation initiative, and one of the strongest legal tools in this field. The legal basis for the designation of Natura 2000 sites is represented by the lists of species and habitats requiring protection included in the Habitats Directive (EU 1992) and the Birds Directive (EU 1979). However, many rural landscape elements, such are temperate wood-pastures cannot be protected as "habitats" under the Habitats Directive since these are either not included or not represented as woodpastures in Annex I of the Directive, Bergmeier et al. (2010) highlighting several inconsistencies in this sense. This is only one example, but the situation is similar for several rural landscape elements. Despite being the strongest legal tool for nature conservation in Europe, the Habitats Directive was unable to keep up with the major changes of the Common Agricultural Policy, the application of which continues to result in rapid land use changes with imminent or expected negative effects on biodiversity (Hochkirch et al., 2013). One reason for this is that conservation science still works with insufficient/improper data which cannot provide evidence for policy development (Pullin et al., 2009), and the lack of knowledge represents a major threat to biodiversity, due to the improper (ill-planned or poorly aligned with local conditions) interventions.

While the highly modified landscapes of Western Europe are relatively well studied, benefiting from repeatedly validated research methodologies, Central and Eastern European farmed landscapes, although recognised as much more diverse, are scientifically less represented, bringing further tasks and challenges for researchers and conservation practitioners (Urbanc et al., 2004; Palang et al., 2006; Schmitt and Rákosy, 2007; 
Cogălniceanu and Cogălniceanu, 2010). Henceforward, there is an urgent need to step across these operational constraints and identify those traditional farmlands and land-use practices worthy of conservation, and treat them as priority conservation management interest (Urbanc et al., 2004; Wright, 2012). In order to achieve effective natural resource management, the traditional (ecological) knowledge of local farmers has to be explored as an integral part of this conservation effort. This would lead to a better understanding of the complex processes governing these ecosystems that also serve as living examples of sustainability. However, the application of traditional practices, although of key importance for biodiversity conservation, hampers the welfare of rural communities in an era that promotes increased productivity and continuous demand for material goods.

At present, Romania is among the few member states where average farm sizes are less than 5 ha, and is leading the list when considering the economic size of the farms (potential gross value added), that takes into account the potential economic productivity of the area used (EC-DGARD, 2010). Subsistence farms are, therefore, characteristic of the country, counting for the highest total number among farm types (Beaufoy et al., 2008). Traditional practices and holding sizes that characterise subsistence farming are known for their deterministic importance in creating and maintaining semi-natural habitats in Transylvania (Mikulcak et al., 2013). Conversely, traditional agriculture is considered less profitable, in terms of financial returns, in comparison with intensive, mechanized practices, and the small-sized subsistence household farms are not even eligible for rural development funding (Beaufoy et al., 2008). This situation will probably force subsistence farmers to give up. The low economic profitability and paucity of opportunities for alternative income, for those living in the area, is already causing land abandonment, intensification and change of land-use. As a member state of the European Union, Romania will have to open its land market to foreigners starting in 2014. The liberalisation of the land market, the competition for agricultural land in Western Europe and the small market price of Romanian land at this moment will be sure to attract important foreign interest. The identity-gap between foreign private owners and these lands will probably result in further losses of areas managed traditionally, unless these owners are committed to the perpetuation of traditions and to the maintenance of ecological services these lands provide, including their exceptional biodiversity.

The conservation of extensively managed rural landscapes is therefore of great actuality; the understanding of their present state and building up scenarios regarding their future evolution has to be based on comprehensive spatial and temporal analyses. These should encompass historical, sociological and economical methodologies and approaches, corroborated with up-to-date data on biodiversity. All these are compulsory for the formulation of proper adaptive management plans and for strong and effective policy actions, aligned with local conditions in an attempt to limit the adverse factors threatening the long-term maintenance of such landscapes of high nature value.

\section{ACKNOWLEDGEMENTS}

This literature study was done as part of the doctoral programme organised by the Institute of Biology - Romanian Academy. The manuscript greatly benefited from the valuable comments of two anonymous reviewers. 


\section{REFERENCES}

Akeroyd, J., Page, N., (2006). The Saxon Villages of Southern Transylvania: Conserving biodiversity in a historic landscape, in: Gafta D. \& Akeroyd J.R. (Eds.) Nature conservation: concepts and practice. (pp. 199-210), Springer, Heidelberg.

Antrop, M., (1997). The concept of traditional landscapes as a base for landscape evaluation and planning. The example of Flanders Region. Landscape and Urban Planning, 38: pp. 105-117. DOI: 10.1016/S0169-2046(97)00027-3.

Antrop, M., (2004). Landscape change and the urbanization process in Europe. Landscape and Urban Planning, 67: pp. 9-26. DOI: 10.1016/S0169-2046(03)00026-4.

Babai, D., Molnár, Zs., (2013). Multidimensionality and scale in a landscape ethnoecological partitioning of a mountainous landscape (Gyimes, Eastern Carpathians, Romania). Journal of Ethnobiology and Ethnomedicine, 9:11. DOI: 10.1186/1746-4269-911.

Baldock, D., Beaufoy, G., Bennett, G. \& Clark, J., (1993). Nature conservation and new directions in the Common Agricultural Policy. IEEP London.

Balmford, A, Green, R. E. \& Scharlemann, J. P. W., (2005). Sparing land for nature: exploring the potential impact of changes in agricultural yield on the area needed for crop production. Global Change Biology, 11: pp. 1594-1605. DOI: 10.1111/j.13652486.2005.001035.x.

Baudry, J., (1989). Interactions between agricultural and ecological systems at the landscape level. Agriculture, Ecosystems and Environment, 27: pp. 119-130. DOI: 10.1016/0167-8809(89)90078-9.

Baur, B., Cremene, C., Groza, G., Rakosy, L., Schileyko, A.A., Baur, A., Stoll, P. \& Erhardt, A., (2006). Effects of abandonment of subalpine hay meadows on plant and invertebrate diversity in Transylvania, Romania. Biological Conservation, 132: pp. 261273. DOI: 10.1016/j.biocon.2006.04.018.

Beaufoy, G., Jones, G., De Rijck, K. \& Kazakova, Y., (2008) High Nature Value farmlands: Recognising the importance of South East European landscapes. Final Summary Report (Bulgaria \& Romania). WWF Danube-Carpathian Programme and European Forum on Nature Conservation and Pastoralism (EFNCP).

Bergmeier, E., Petermann, J. \& Schröder E., (2010) Geobotanical survey of wood-pasture habitats in Europe: diversity, threats and conservation. Biodiversity and Conservation, 19: pp. 2995-3014. DOI: 10.1007/s10531-010-9872-3.

Bignal, E. M. \& McCracken D. I., (1996). Low-intensity farming systems in the conservation of the countryside. Journal of Applied Ecology, 33: pp. 413-424. DOI: $10.2307 / 2404973$.

Bouma, J., Varallyay, G. \& Batjes, N. H., (1998). Principal land use changes anticipated in Europe. Agriculture, Ecosystems and Environment, 67: pp. 103-119. DOI: 10.1016/S01678809(97)00109-6.

Cogălniceanu, D. \& Cogălniceanu, G-C., (2010). An enlarged European Union challenges priority settings in conservation. Biodiversity and Conservation, 19: pp. 1471-1483. DOI: 10.1007/s10531-010-9777-1.

Cousins, S. A. O., (2009). Landscape history and soil properties affect grassland decline and plant species richness in rural landscapes. Biological Conservation, 142: pp. 2752 2758. DOI:10.1016/j.biocon.2009.07.001. 
Cowell, M., (2007). Future land use change in a traditionally farmed landscape in Eastern Europe (Transylvania, Romania). Transylvanian Review of Systematical and Ecological Research, 4: pp. 199-216.

Dutoit, T., Buisson, E., Roche, P. \& Alard, D., (2003). Land use history and botanical changes in the calcareous hillsides of Upper-Normandy (north-western France): new implications for their conservation management. Biological Conservation, 115: pp. 1-19. DOI: 10.1016/S0006-3207(03)00089-2.

EC-DGARD - European Commission, Directorate-General for Agriculture and Rural Development (2010). Situation and prospects for EU agriculture and rural areas. Report, $65 \mathrm{p}$.

European Environmental Agency, (2004). High nature value farmland - Characteristics, trends and policy changes. Copenhagen: European Environmental Agency.

Eetvelde, V. V. \& Antrop, M., (2009). Indicators for assessing changing landscape character of cultural landscapes in Flanders (Belgium). Land Use Policy, 26: pp. 901-910. DOI: 10.1016/j.landusepol.2008.11.001.

Enyedi, Z. M., Ruprecht, E. \& Deák, M., (2008). Long-term effects of the abandonment of grazing on steppe-like grasslands. Applied Vegetation Science, 11: pp. 55-62. DOI: 10.1111/j.1654-109X.2008.tb00204.x.

Fahrig, L., (2007). Non-optimal animal movement in human-altered landscapes. Functional Ecology, 21: pp. 1003-1015. DOI:10.1111/j.1365-2435.2007.01326.x.

Fang, S., Gertner, G., Wang, G. \& Anderson, A., (2006). The impact of misclassification in land use maps in the prediction of landscape dynamics. Landscape Ecology, 21: pp. 233242. DOI: 10.1007/s10980-005-1051-7.

Felton, A., Knight, E., Wood, J., Zammit, C. \& Lindenmayer, D., (2010). A meta-analysis of fauna and flora species richness and abundance in plantations and pasture lands. Biological Conservation, 143: pp. 545-554. DOI: 10.1016/j.biocon.2009.11.030.

Foley, J.A., DeFries, R., Asner, G. P., Barfordm C., Bonan, G., Carpenter, S. R., Chapin, F. S., Coe, M. T., Daily, G. C., Gibbs, H. K., Helkowski, J. H., Holloway, T., Howard, E. A., Kucharik, C. J., Monfreda, C., Patz, J. A., Prentice, I. C., Ramankutty, N. \& Snyder P. K., (2005). Global Consequences of Land Use. Science, 309: pp. 570-574. DOI: 10.1126/science.1111772.

Foster, D., Swanson, F., Aber, J., Burke, I., Brokaw, N., Tilman, D. \& Knap A., (2003). The importance of land-use legacies to ecology and conservation. BioScience, 53: pp. 7788. DOI: 10.1641/0006-3568(2003)053[0077:TIOLUL]2.0.CO;2.

Green, R. E., Cornell, S. J, Scharlemann, J. P. W. \& Balmford, A., (2005). Farming and the fate of wild nature. Science, 307: pp. 550-555. DOI: 10.1126/science.1106049.

Halada L., Evans D., Romão C. \& Petersen J-E., (2011). Which habitats of European importance depend on agricultural practices? Biodiversity and Conservation, 20: pp. 23652378. DOI: 10.1007/s10531-011-9989-z.

Hanski, I., (2001). Spatially realistic metapopulation theory. Naturwissenschaften, 88: pp. $372-381$.

Hartel, T., Schweiger, O., Öllerer, K., Cogălniceanu, D., Arntzen, J.W., (2010). Amphibian distribution in a traditionally managed rural landscape of Eastern Europe: probing the effect of landscape composition. Biological Conservation, 143: pp. 1118-1124. DOI: 10.1016/j.biocon.2010.02.006. 
Hietala-Koivu, R., Järvenpää, J. \& Helenius J., (2004). Value of semi-natural areas as biodiversity indicators in agricultural landscapes. Agriculture, Ecosystems and Environment, 101: pp. 9-19. DOI: 10.1016/S0167-8809(03)00273-1.

Hochkirch, A., Schmitt, T., Beninde, J., Hiery, M., Kinitz, T., Kirschey, J., Matenaar, D.,Rohde, K., Stoefen, A., Wagner N., Zink, A., Lötters, S., Veith, M., \& Proelss, A., (2013) Europe needs a new vision of the Natura 2000 network? Conservation Letters (in press), DOI: $10.1111 /$ conl.12006.

Houlahan, J. E., Keddy, P.A., Makkay, K. \& Findlay C. S., (2006). The effects of adjacent land use on wetland species richness and community composition. Wetlands, 26: pp. 79-96. DOI: 10.1672/0277-5212(2006)26[79:TEOALU]2.0.CO;2.

Huston, M. A., (2005). The three phases of land-use change: implications for biodiversity. Ecological Applications, 15: pp. 1864-1878.

Jongman, R. H. G., (2002). Landscape planning for biological diversity in Europe. Landscape Research, 27: pp. 187-195. DOI: 10.1080/01426390220128668.

Kleijn, D., Baquero, R. A., Clough, Y., Díaz, M., Esteban, J., Fernández, F., Gabriel, D., Herzog, F., Holzschuh, A., Jöhl, R., Knop, E., Kruess, A., Marshall, E. J. P., SteffanDewenter, I., Tscharntke, T., Verhulst, J., West, T. M. \& Yela, J. L., (2007). Mixed biodiversity benefits of agri-environment schemes in five European countries. Ecology Letters, 9: pp. 243-254. DOI: 10.1111/j.1461-0248.2005.00869.x.

Kleijn, D., Kohler, F., Báldi, A., Batáry, P., Concepción, E. D., Clough, Y., Díaz, M., Gabriel, D., Holzschuh, A., Knop, E., Kovács, A., Marshall, E. J., Tscharntke, T. \& Verhulst, J., (2009). On the relationship between farmland biodiversity and land-use intensity in Europe. Proceedings of the Royal Society B., 276: pp. 903-909. DOI: 10.1098/rspb.2008.1509.

Kleijn, D., \& Sutherland W.J., (2003) How effective are European agri-environment schemes in conserving and promoting biodiversity? Journal of Applied Ecology, 40: pp. 947-969. DOI: 10.1111/j.1365-2664.2003.00868.x/pdf.

Kremen, C., Williams, N. M., Aizen, M. A., Gemmill-Herren, B., LeBuhn, G., Minckley, R., Packer, L., Potts, S. G., Roulston, T., Steffan-Dewenter, I., Vázquez, D. P. , Winfree, R., Adams, L., Crone, E. E., Greenleaf, S. S., Keitt, T. H., Klein, A-M., Regetz, J. \& Ricketts, T. H., (2007). Pollination and other ecosystem services produced by mobile organisms: a conceptual framework for the effects of land-use change. Ecology Letters, 10: pp. 99-314. DOI: 10.1111/j.1461-0248.2007.01018.x.

Laliberté, E., Wells, J.A., DeClerck, F., Metcalfe, D. J., Catterall, C. P., Queiroz, C., Aubin, I., Bonser, S. P., Ding, Y., Fraterrigo, J. M., McNamara, S., Morgan, J. W., Sánchez, M. D., Vesk, P. A. \& Mayfield, M. M., (2010). Land-use intensification reduces functional redundancy and response diversity in plant communities. Ecology Letters, 13: pp. 76-86. 10.1111/j.1461-0248.2009.01403.x.

Levins, R., (1969). Some demographic and genetic consequences of environmental heterogeneity for biological control. Bulletin of the Entomological Society of America, 15: pp. 237-240.

MacArthur, R. H. \& Wilson, E. O., (1967). The Theory of Island Biogeography. Princeton: Princeton University Press.

Mattison, E. H. A. \& Norris, K., (2005). Bridging the gaps between agricultural policy, land-use and biodiversity. Trends in Ecology and Evolution, 20: pp. 610-616. DOI: 10.1016/j.tree.2005.08.011. 
McIntyre, S. \& Lavorel, S., (2007). A conceptual model of land use effects on the structure and function of herbaceous vegetation. Agriculture, Ecosystems and Environment, 119: pp. 11-21. DOI: 10.1016/j.agee.2006.06.013.

Mikulcak, F. Newig, J., Milcu A.I., Hartel T. \& Fisher J., (2013) Integrating rural development and biodiversity conservation in Central Romania. Environmental Conservation, 40(2): pp. 129-137. DOI: 10.1017/S0376892912000392.

Molnár, Zs. \& Babai, D., (2009). Comparison of traditional Hungarian Csángó and scientific habitat-related knowledge, in: Splechtna B. (Ed.) Proceedings of the International Symposium: Preservation of Biocultural Diversity, (pp. 133-141), University of Natural Resource Management and Applied Life Sciences, Vienna.

Noy-Meir, I., Gutman M. \& Kaplan, Y., (1989). Responses of Mediterranean grassland plants to grazing and protection. Journal of Ecology, 77: pp. 290-310.

Oliver, R., Roy, D. B., Hill, J.K., Brereton, T. \& Thomas, C. D. (2010). Heterogeneous landscapes promote population stability. Ecology Letters, 13: pp. 473-484. DOI: 10.1111/j.1461-0248.2010.01441.x.

Palang, H., Printsmann, A., Konkoly-Gyuró, É., Urbanc, M., Skowronek, E. \& Woloszyn, W., (2006). The forgotten rural landscapes of Central and Eastern Europe. Landscape Ecology, 21: pp. 347-357. DOI: 10.1007/s10980-004-4313-X.

Paracchini, M.L., Petersen, J.-E., Hoogeveen, Y., Bamps, C., Burfield, I., \& van Swaay, C., (2008). High Nature Value Farmland in Europe - An estimate of the distribution patterns on the basis of land cover and biodiversity data. Report EUR $23480 \mathrm{EN}$.

Pedroli, B, van Doorn, A, de Blust, G, Paracchini, M.L., Wascher, D. \& Bunce, F., (Eds., 2007). Europe's Living Landscapes. Essays on exploring our identity in the countryside. KNNV, LANDSCAPE EUROPE Publishing, The Netherlands.

Pereira, H. M. \& Daily G., (2006). Modeling biodiversity dynamics in countryside landscapes. Ecology, 87: pp. 1877-1885. DOI: 10.1890/0012-9658(2006)87 [1877:MBDICL]2.0.CO;2.

Phillips, A., (1998). The nature of cultural landscapes - a nature conservation perspective. Landscape Research, 23: pp. 21-38. DOI: 10.1080/01426399808706523.

Pickett, S. T. A. \& Cadenasso, M. L., (1995). Landscape ecology: spatial heterogeneity in ecological systems. Science, 269: pp. 331-334. DOI: 10.1126/science.269.5222.331.

Plieninger, T., Höchtl, F. \& Spek, T., (2006). Traditional land-use and nature conservation in European rural landscapes. Environmental Science and Policy, 9: pp. 317-321. DOI: 10.1016/j.envsci.2006.03.001.

Plieninger, T. \& Bieling C., (Eds., 2012). Resilience and the Cultural Landscape. Understanding and Managing Change in Human-Shaped Environments. Cambridge University Press, Cambridge.

Pocewicz, A., Nielsen-Pincus, M., Goldberg, C. S., Johnson, M.H., Morgan, P., Force, J. E., Waits, L. P. \& Vierling, L., (2008). Predicting land use change: comparison of models based on landowner surveys and historical land cover trends. Landscape Ecology, 23: pp. 195-210. DOI: 10.1007/s10980-007-9159-6.

Pullin, A.S., Báldi, A., Can, O.E., Dieterich, M., Kati, V., Livoreil, B., Lövei, G., Mihók, B., Nevin, O., Selva, N., Sousa-Pinto, I., (2009). Conservation focus in Europe: major conservation policy issues that need to be informed by conservation science. Conservation Biology, 23: pp. 818-824. DOI: 10.1111/j.1523-1739.2009.01283.x. 
Rabbinge, R. \& van Diepen, C.A., (2000). Changes in agriculture and land use in Europe. European Journal of Agronomy, 13: pp. 85-99. DOI: 10.1016/S1161-0301(00)00067-8.

Rick, T. C. \& Lockwood R., (2012). Integrating paleobiology, archeology, and history to inform biological conservation. Conservation Biology, DOI: 10.1111/j.15231739.2012.01920.x.

Ruprecht, E., Enyedi, M. Z., Eckstein, L. \& Donath, T. W., (2010). Restorative removal of plant litter and vegetation 40 years after abandonment enhances re-emergence of steppe grassland vegetation. Biological Conservation, 143: pp. 449-456. DOI: 10.1016/j.biocon.2009.11.012.

Sanderson, E. W., Redford, K. H., Vedder A., Coppolillo, P. B. \& Ward, S., (2002). A conceptual model for conservation planning based on landscape species requirements. Landscape and Urban Planning, 58: pp. 41-56. DOI: 10.1016/S0169-2046(01)00231-6.

Scheper, J., Holzschuh, A., Kuussaari, M., Potts, S.G., Rundlöf, M., Smith, H.G. and Kleijn D., (2013). Environmental factors driving the effectiveness of European agri-environmental measures in mitigating pollinator loss - a meta-analysis. Ecology Letters (in press) DOI: 10.1111/ele.12128.

Schmitt, T. \& Rákosy L., (2007). Changes of traditional agrarian landscapes and their conservation implications: a case study of butterflies in Romania. Diversity and Distribution, 13: pp. 855-862. DOI: 10.1111/j.1472-4642.2007.00347.x.

Schneider, C. \& Gry, G., (2005). Estimating the consequences of land-use changes on butterfly diversity in a marginal agricultural landscape in Sweden. Journal for Nature Conservation, 13: pp. 247-256. DOI: 10.1016/j.jnc.2005.02.006.

Sousa, A. \& García-Murillo, P., (2001). Can place names be used as indicators of landscape changes? Application to the Doñana Natural Park (Spain). Landscape Ecology, 16: pp. 391-406. DOI: 10.1023/A:1017585101389.

Strijker, D., (2005). Marginal lands in Europe - causes of decline. Basic and Applied Ecology, 6: pp. 99-106. DOI: 10.1016/j.baae.2005.01.001.

Theobald, D. M., Hobbs, N. T., Bearly, T., Zack, J. A., Shenk, T. \& Riebsame, W. E., (2000). Incorporating biological information in local land-use decision making: designing a system for conservation planning. Landscape Ecology, 15: pp. 35-45. DOI: 10.1023/A:1008165311026.

Troll, C., (1939). Luftbildplan and okologische bodenforschung. Zeitschraft der Gesellschaft fur Erdkunde: pp. 241-298.

Tscharntke, T., Klein, A. M., Kruess, A., Steffan-Dewenter, I. \& Thies, C., (2005). Landscape perspectives on agricultural intensification and biodiversity - ecosystem service management. Ecology Letters, 8: pp. 857-874.

Urbanc, M., Printsmann, A., Palang, H., Skowronek, E., Woloszyn, W. \& Konkoly-Gyuró, E., (2004). Comprehension of rapidly transforming landscapes of Central and Eastern Europe in the 20th century. Acta Geographica Slovenica, 44: pp. 101-131.

Van Noordwijk, M., Poulsen, J. G. \& Ericksen P. J., (2004). Quantifying off-site effects of land use change: filters, flows and fallacies. Agriculture, Ecosystems and Environment, 104: pp. 19-34.

Vitousek, P. M., Mooney, H. A., Lubchenco, J. \& Melillo, J. M., (1997). Human domination of Earth's ecosystems. Science, 277: pp. 494-499. DOI: 10.1126/science.277.5325.494. 
Wagner, H. H. \& Fortin, M-J., (2005). Spatial analysis of landscapes: concepts and statistics. Ecology, 86: pp. 1975-1987. DOI: 10.1890/04-0914.

Wright, H. L., Lake, I. R. \& Dolman, P.M., (2012). Agriculture - a key element for conservation in the developing world. Conservation Letters, 5: pp. 11-19. DOI: 10.1111/j.1755-263X.2011.00208.x. 